\title{
Kompetensi Guru: Metode Praktik dalam Pembelajaran IPA
}

\author{
Maya Agustina'; Havea Juliar Apko² \\ STAIN Teungku Dirundeng Meulaboh Aceh Indonesia ${ }^{1,2}$ \\ mayaagustn@staindirundeng.ac.id
}

\begin{abstract}
This study aims to determine the science teacher of elementary school perceptions in learning science with practical methods. Research carried out by the method blending, mixing qualitative and quantitative. The subjects of the study were Science Teacher and head of MIN (elementary school) Aceh Jaya District. The instrument used was in the form of a teacher's perception questionnaire which was arranged based on a Likert scale and a list of interview questions. The results showed that the perception of teachers in "very good" category was $92 \%$ and the remaining $8 \%$ were in the "quite good" category. The result of the interviews showed that the teachers of MIN (elementary school) already understood the importance of learning science with practical methods, but the inadequate facilities and infrastructure caused practicum in science teaching to be rarely carried out.
\end{abstract}

Keywords: Teacher's Perception, Learning Science, Practical Methods.

\begin{abstract}
Abstrak
Penelitian ini bertujuan untuk mengetahui Persepsi Guru IPA MIN dalam Pembelajaran IPA dengan Metode Praktikum. Penelitian dilakukan dengan metode blending, mixing qualitative and quantitative. Subjek penelitian ini adalah Guru IPA dan Kepala MIN se-kabupaten Aceh Jaya. Instrumen yang digunakan berupa angket Persepsi Guru yang disusun berdasarkan skala Likert dan daftar pertanyaan wawancara untuk guru IPA dan kepala sekolah. Hasil penelitian menunjukkan bahwa persepsi guru berada pada kategori "sangat baik" yaitu sebesar 92\% dan sisanya sebesar $8 \%$ berada pada kategori "cukup baik". Hasil wawancara menunjukkan bahwa guru IPA MIN sudah sangat memahami arti pentingnya pembelajaran IPA dengan metode praktikum, namun karena sarana dan prasarana yang belum memadai menyebabkan praktikum dalam pembelajaran IPA jarang dilaksanakan.
\end{abstract}

Kata Kunci: Persepsi Guru, Pembelajaran IPA, Metode Praktikum 


\section{A. Pendahuluan}

Pembelajaran IPA terpadu merupakan salah satu model implementasi kurikulum yang dianjurkan untuk diaplikasikan dijenjang pendidikan dasar karna pembelajaran IPA merupakan wahana untuk membekali peserta didik dengan pengetahuan, ketrampilan, dan sikap yang diperlukan untuk memahami dan menyesuaikan diri terhadap fenomena dan perubahanperubahan di lingkungan sekitar dirinya (Fauzan, Gani, Syukri, Aceh, \& Banda, 2017; Forefry, 2017). Melalui pembelajaran IPA diharapkan siswa dapat memahami segala fenomena ilmiah yang terjadi di alam sekitar. Banyak hal yang dapat dibuktikan melalui pembelajaran IPA dengan metode praktek. Pembelajaran seperti ini akan membuat siswa menarik untuk belajar.

Salah satu tugas pendidik adalah mengembangkan potensi siswa. Potensi yang dimaksud adalah potensi scientis siswa yang distimulus secara optimal sejak dini melalui proses pembelajaran IPA yang dikelola secara profesional. Potensi scientis dibawa oleh siswa dalam serangkaian kegiatan sehari-hari, berhadapan dengan dunia IPA yang sederhana sampai yang membutuhkan pengetahuan kompleks. Sehingga secara intrinsik, siswa akan terdorong untuk mengerti dan menelusuri apa saja yang termasuk dan berkaitan dengan IPA. Dorongan untuk ingin mengetahui segala sesuatu hadir karena IPA membuat siswa penasaran dengan apa yang terjadi di alam.

Potensi scientis peserta didik tentu dipengaruhi oleh beberapa faktor di antaranya kualitas pendidikan yang baik, sarana dan prasarana yang memadai dan guru IPA yang memahami pentingnya penerapan metode praktikum dalam pembelajaran. Sarana dan prasarana yang memadai dapat mempengaruhi kemampuan peserta didik dalam mempelajari sains. Hal ini perlu diperhatikan oleh penyedia sarana agar keberadaan sarana terpenuhi. Kelengkapan sarana dan prasarana yang dimiliki oleh setiap sekolah seperti laboratorium IPA akan memudahkan guru dalam melaksanakan tugasnya dalam menciptakan suasana belajar yang kreatif, inovatif, menarik dan 
bermakna. Kemampuan guru dalam mengelola laboratorium dengan baik didukung sarana dan prasarana yang memadai dan siswa yang sangat mendukung dalam pemanfaatan laboratorium sebagai sumber belajar dan dapat membantu siswa dalam belajar (Husna, 2011). Meskipun, sebagai seorang guru juga dituntut untuk memikirkan cara alternatif agar praktik tetap harus dilakukan tanpa sarana yang memadai.

Peserta didik akan lebih terbantu dengan adanya sarana dan prasarana pembelajaran seperti laboratorium IPA, karna tidak semua peserta didik memiliki tingkat kecerdasan yang baik dalam menangkap maksud pembelajaran yang disampaikan oleh guru, sehingga penggunaan sarana pembelajaran seperti laboratorium IPA dapat membantu peserta didik dalam memahami materi yang dipelajari, sehingga belajar akan lebih terasa menarik dan bermakna. Hal ini memberikan bukti bahwa alat/sarana dan intensitas penggunaan laboratorium memiliki kontribusi yang signifikan terhadap hasil belajar siswa, dimana melalui pembelajaran dengan praktikum siswa dapat meningkatkan hasil belajar (Damarwulan, 2020; Yanti, Subiki, \& Yushardi, 2016). Lebih lanjut Nafiah \& Suyanto (2014) menyatakan bahwa sarana dan prasarana yang memadai dan memenuhi standar yang tersedia di laboratorium dapat membantu siswa dalam melaksanakan praktikum, sehingga siswa mudah dalam memahami materi yang diajarkan.

Keberadaan laboratorium dan guru yang siap melakukan praktikum dapat meningkatkan keterampilan generik sains karena keterampilan ini menjadi dasar yang harus dimiliki oleh seseorang yang berkecimpung dibidang sains. Adanya keterampilan dasar pada siswa sangat membantu siswa dalam menerima materi IPA. Memalui keterampilan dasar tersebut siswa belajar untuk memiliki tingkat keterampilan yang lebih tinggi. Kemampuan guru dalam bidang praktek sangat dibutuhkan untuk menunjang pemanfaatan sarana dan prasarana di laboratorium (Fadilah, Sari, Ramadhani, Basuki, \& Fitaloka, 2019; Jalil, 2019; Kumalasari, 2019). 
Penyediaan sarana dan prasarana sebagai pelengkap pelaksanaan pendidikan merupakan tugas dan kewajiban utama bagi satuan pendidikan (sekolah/madrasah), dan secara khusus lagi dalam Standar Pelayanan Minimal (SPM) Sekolah/Madrasah dinyatakan bahwa setiap satuan pendidikan wajib memiliki prasarana yang termasuk diantaranya ialah ruang laboratorium (Nasional, 1982).

Ruang laboratorium yang tersedia memaksimalkan pelaksanaan pembelajaran IPA, selain sarana pembelajaran dalam bentuk laboratorium IPA yang menjadi pendukung pembelajaran, maka perlu juga diperhatikan rasio minimal kelengkapan dan keragaman jenis peralatan laboratorium yang harus dimiliki perpeserta didik dalam satu sekolah seperti yang tercantum dalam UUD pasal 43 ayat 1 dan 2 . Ini cukup memberikan bukti bahwa penting adanya laboratorium bagi pelajaran yang membutuhkan praktek. Waktu yang sangat terbatas guru tetap bisa melakukan praktikum, maka dari segi itu dituntut kreatifitas guru dalam memanfaatkan waktu tersebut sehingga dapat dipergunakan seefektif mungkin dan membantu siswa dalam belajar (Nur, 2012; Pantiwati, 2015).

Kurikulum K13 memberikan alternatif terbaik bagi guru dalam menyampaikan informasi dengan baik dan menarik kepada peserta didik, tetapi sangat disayangkan sampai saat ini masih ada guru yang belum bisa menjalankan amanat kurikulum K13, disebabkan oleh banyak hal dalam menyikapi paradigma baru dunia pendidikan yang belum dikuasai sepenuhnya oleh guru. Akibatnya proses pembelajaran didalam kelas masih banyak guru yang masih melaksanakan pembelajaran dengan pola lama yang hanya mengajar menghabiskan materi di dalam buku tanpa mengacu pada standar kompetensi dan kompetensi dasar yang ingin dicapai (Budiani \& Syamwil, 2017; Kastina \& Sujianto, 2017). Ini tentu jauh dari capaian yang diharapkan oleh kurikulum K13 yang menitikberatkan pada pencapaian dari setiap materi yang diajarkan. 
Pasca gempa dan tsunami, Calang masih sebagai salah satu kawasan yang sedang berbenah untuk lebih maju. Berdasarkan hasil penelitian terkait infrastruktur Kota Calang pasca tsunami 2005-2016 terlihat adanya perkembangan ke arah yang lebih baik terutama dalam aspek fasilitas umum yang tidak bisa dilepaskan dari kelancaran aktivitas masyarakat Kota Calang. Infrastruktur yang paling utama ditingkatkan oleh pemerintah Kabupaten Aceh Jaya ini ialah sarana transportasi jalan, Kesehatan, dan Pendidikan. meskipun calang merupakan daerah yang baru dan masih dalam tahap berkembang, namun bisa di golongkan kedalam daerah yang berkembang pesat. Perkembangan ini tentu seiring dengan perkembangan dibidang pendidikan.

Berdasarkan survei awal peneliti dalam menggali informasi seputar fenomena belajar mengajar yang diterapkan di MIN yang ada di Aceh Jaya, informasi yang diberikan oleh ketua FASDA Aceh Jaya bahwa fenomena belajar yang terjadi pada pembelajaran IPA dibeberapa MI di Kabupaten Aceh Jaya saat ini sudah berjalan dengan cukup baik, namun masih dalam konteks belajar hanya dengan memanfaatkan buku teks, dan belum menerapkan pembelajaran IPA dengan metode praktikum. Padahal dalam pembelajaran IPA sangat dibutuhkan praktikum agar peserta didik lebih mudah memahami materi yang dipelajari, pembelajaran juga akan lebih bermakna dan dapat merangsang rasa ingin tau siswa untuk belajar sendiri serta mencari sendiri fakta-fakta berdasarkan konsep ilmiah yang sudah ada sebelumnya.

Informasi awal yang peneliti dapatkan tersebut menjadi alasan utama bagi peneliti untuk mencoba mengkaji hal yang terkait dengan pembelajaran IPA, maka peneliti tertarik untuk memperdalam informasi tentang mengapa sebahagian besar guru MIN pada Kabupaten Aceh Jaya masih belum membudayakan pembelajaran dengan metode praktikum. Bukti lain juga membuktikan bahwa rata-rata nilai akhir IPA siswa yaitu 67 dan ini masih dibawah kkm yang berada pada angka 70. Ini membuktikan bahwa adanya masalah yang dihadapi oleh siswa dalam pelajaran IPA sehingga hasilnya 
rendah. Sehingga untuk mendapatkan informasi tersebut peneliti melakukan penelitian dengan judul Analisis Persepsi Guru IPA MIN Sekabupaten Aceh Jaya Terhadap Pembelajaran IPA dengan Metode Praktikum.

\section{B. Metode}

Penelitian dilakukan di kabupaten Aceh Jaya. Populasi penelitian adalah seluruh guru IPA Madrasah Ibtidaiyah Negeri se-kabupaten Aceh Jaya. Pemilihan sampel penelitian dilakukan secara random sampling. Sampel penelitian adalah 14 kepala MIN dan26 orang guru IPA MIN se-kabupaten Aceh Jaya. Tahapan penelitian dibagi menjadi dua tahapan utama yaitu tahapan persiapan penelitian, tahapan pelaksanaan dan tahapan analisis data dan kesimpulan. Tahapan persiapan penelitian meliputi studi pendahuluan, penyusunan instrumen penelitian dan validasinya. Selanjutnya adalah tahapan pelaksanaan yaitu penyebaran instrumen penelitian untuk diisi oleh guru sekaligus melakukan wawancara dengan kepala sekolah dan guru.

Instrumen penelitian yang digunakan dan teknik pengumpulan data dapat dilihat pada Tabel 1.

Tabel 1 Instrumen dan teknik pengumpulan data

\begin{tabular}{ccccc}
\hline No & $\begin{array}{c}\text { Sumber } \\
\text { data }\end{array}$ & Data yang diperoleh & $\begin{array}{c}\text { Teknik pengumpulan } \\
\text { data }\end{array}$ & Instrumen \\
\hline 1 & $\begin{array}{c}\text { Kepala } \\
\text { sekolah } \\
\text { Guru }\end{array}$ & Pembelajaran IPA & Wawancara & Lembar wawancara \\
2 & Guru & $\begin{array}{c}\text { Kendala yang } \\
\text { dihadapi dalam } \\
\text { pembelajaran IPA }\end{array}$ & Wengisian angket & $\begin{array}{c}\text { Angket berhubungan dengan } \\
\text { Persepsi guru IPA }\end{array}$ \\
& & & Lembar wawancara \\
\hline
\end{tabular}

Data yang diperoleh dari hasil wawancara dengan guru dan kepala sekolah selanjutnya dianalisis dan dideskripsikan. Deksripsi ini bertujuan untuk menggambarkan keadaan sekolah dan keadaan pembelajaran IPA di masing-masing lokasi penelitian. Kategori persepsi guru IPA dibagi kedalam 3 kategori yaitu rendah, sedang dan tinggi. 
Tabel 2 Kategori persepsi guru IPA

\begin{tabular}{cc}
\hline Rentang Skor & Kategori Persepsi Guru IPA \\
\hline $84-112$ & Sangat Baik \\
$57-83$ & Cukup Baik \\
$28-56$ & Tidak Baik \\
\hline
\end{tabular}

\section{Hasil dan Pembahasan}

Hasil penelitian dan pembahasan dituliskan secara terpisah pada penjelasan di bawah ini. Pada poin hasil hanya dituliskan hasil penelitian berdasarkan angket.

\section{Hasil}

Setelah penelitian diketahui hasil angket yang diberikan kepada guruguru yang ada di MIN Aceh Jaya. Hasil Angket diolah dan didapatkan hasil seperti pada tabel 3 berikut ini.

Tabel 3 hasil angket persepsi guru terhadap pembelajaran IPA

\begin{tabular}{|c|c|c|c|c|c|}
\hline \multirow[t]{2}{*}{ No } & \multirow[t]{2}{*}{ Pernyataan } & \multicolumn{4}{|c|}{ Persentase jawaban (\%) } \\
\hline & & SS & $\mathbf{S}$ & TS & STS \\
\hline 1 & $\begin{array}{l}\text { Guru mengetahui dengan baik pentingnya praktikum dalam } \\
\text { pembelajaran IPA }\end{array}$ & 57,7 & 38,5 & 3,85 & 0 \\
\hline 2 & $\begin{array}{l}\text { Pembelajaran IPA tidak harus dilakukan dengan metode } \\
\text { praktikum }\end{array}$ & 0 & 61,5 & 30,8 & 7,69 \\
\hline 3 & $\begin{array}{l}\text { Pembelajaran IPA tidak sekedar melakukan kegiatan } \\
\text { praktikum akan tetapi juga mentransfer keterampilan } \\
\text { merencanakan penyelidikan ilmiah, merumuskan } \\
\text { pertanyaan serta merancang percobaan }\end{array}$ & 42,3 & 53,8 & 3,85 & 0 \\
\hline 4 & $\begin{array}{l}\text { Keterbatasan jam pelajaran dapat saya manfaatkan dengan } \\
\text { efektif dan efisien untuk melakukan praktikum }\end{array}$ & 26,9 & 46,2 & 26,9 & 0 \\
\hline 5 & $\begin{array}{l}\text { Sedikitnya jam pelajaran IPA menyebabkan kegiatan } \\
\text { praktikum tidak dapat dilaksanakan }\end{array}$ & 3,85 & 53,8 & 38,5 & $\begin{array}{c}3,8 \\
5\end{array}$ \\
\hline 6 & $\begin{array}{l}\text { Kegiatan praktikum yang tidak cukup waktu membuat siswa } \\
\text { kurang leluasa dalam mengembangkan ketrampilan dan } \\
\text { memenuhi rasa ingin tahunya. }\end{array}$ & 30,1 & 61,5 & 7,69 & 0 \\
\hline 7 & $\begin{array}{l}\text { Guru sering menggunakan media pembelajaran dalam } \\
\text { mengajar IPA }\end{array}$ & 38,5 & 57,7 & 38,5 & 0 \\
\hline 8 & $\begin{array}{l}\text { Guru jarang memanfaatkan alat dan bahan yang ada } \\
\text { dilingkungan sekitar dalam mengajar IPA }\end{array}$ & 23,1 & 57,7 & 15,4 & 3,85 \\
\hline 9 & $\begin{array}{l}\text { Guru Sering menggunakan cara alternatif dalam } \\
\text { menyampaikan materi untuk menghindari melakukan } \\
\text { praktikum }\end{array}$ & 11,5 & 34,6 & 38,5 & 15,4 \\
\hline 10 & $\begin{array}{l}\text { Semua alat dan bahan yang digunakan untuk praktikum } \\
\text { harus di ketahui oleh guru fungsi dan cara penggunaannya }\end{array}$ & 65,4 & 30,8 & 3,85 & 0 \\
\hline 11 & $\begin{array}{l}\text { Penting bagi guru untuk mengetahui fungsi alat dan bahan } \\
\text { praktikum agar guru mengerti cara memanfaatkannva }\end{array}$ & 65,4 & 23,1 & 7,69 & 0 \\
\hline
\end{tabular}




\begin{tabular}{|c|c|c|c|c|c|}
\hline \multirow[t]{2}{*}{ No } & \multirow[t]{2}{*}{ Pernyataan } & \multicolumn{4}{|c|}{ Persentase jawaban (\%) } \\
\hline & & SS & $\mathbf{S}$ & TS & STS \\
\hline 12 & $\begin{array}{l}\text { Pemanfaatan, penyimpanan, pemeliharaan dan perbaikan } \\
\text { alat yang digunakan untuk kegiatan praktikum harus } \\
\text { dikuasai dengan baik oleh guru IPA }\end{array}$ & 61,5 & 38,5 & 0 & 0 \\
\hline 13 & $\begin{array}{l}\text { Sebaiknya LKS yang diberikan kepada siswa dimodifikasi } \\
\text { semenarik mungkin (kertas, huruf, gambar) sesuai dengan } \\
\text { kondisi praktikum yang ingin dilaksanakan agar } \\
\text { meningkatkan motivasi siswa dalam melakukan praktikum }\end{array}$ & 50 & 46,2 & 3,85 & 0 \\
\hline 14 & LKS tidak begitu berperan dalam melakukan praktikum & 19,2 & 53,8 & 23,1 & 3,85 \\
\hline 15 & Saya menguasai materi IPA dengan sangat baik & 7,69 & 73,1 & 19,2 & 0 \\
\hline 16 & $\begin{array}{l}\text { Praktikum IPA dapat dilakukaan meskipun tidak adanya } \\
\text { penuntun praktikum }\end{array}$ & 11,5 & 50 & 30,8 & 7,69 \\
\hline 17 & $\begin{array}{l}\text { Pemberian pendidikan IPA di sekolah dasar bertujuan untuk } \\
\text { memberi pemahaman kepada siswa agar lebih mencintai } \\
\text { dan menghargai lingkungan }\end{array}$ & 69,2 & 30,8 & 0 & 0 \\
\hline 18 & $\begin{array}{l}\text { Selalu mengikuti perkembangan IPA baik melalui pelatihan- } \\
\text { pelatihan atau melalui media sosial lainnya untuk } \\
\text { mendapatkan informasi terbaru tentang IPA }\end{array}$ & 42,3 & 53,8 & 3,85 & 0 \\
\hline 19 & $\begin{array}{l}\text { Mengarahkan siswa untuk membuat kliping tentang isu-isu } \\
\text { terbaru dalam pembelajaran IPA dari berbagai media massa } \\
\text { yang beredar di masyarakat. }\end{array}$ & 30,8 & 65,4 & 3,85 & 0 \\
\hline 20 & $\begin{array}{l}\text { Menjadi guru yang profesional tidak harus mengetahui } \\
\text { karakter siswanya }\end{array}$ & 34,6 & 46,2 & 15,4 & 3,85 \\
\hline 21 & $\begin{array}{l}\text { Pembagian siswa dalam kelompok belajar disesuaikan } \\
\text { dengan tingkat pemahaman siswa agar kelompok belajar } \\
\text { heterogen }\end{array}$ & 15,4 & 76,9 & 3,85 & 0 \\
\hline 22 & $\begin{array}{l}\text { Pada saat praktikum berlangsung guru mengingatkan } \\
\text { kembali tahap-tahap praktikum kepada siswa sesuai } \\
\text { penuntun }\end{array}$ & 46,2 & 53,8 & 0 & 0 \\
\hline 23 & $\begin{array}{l}\text { Guru tidak perlu mengenal atau memahami karakter siswa } \\
\text { asalkan materi ajar dikuasai oleh guru }\end{array}$ & 26,9 & 53,8 & 15,4 & 3,85 \\
\hline 24 & $\begin{array}{l}\text { Jika pada saat melakukan praktikum di kelas siswa terlihat } \\
\text { bosan, maka siswa diarahkan praktikum di alam terbuka }\end{array}$ & 61,5 & 38,5 & 0 & 0 \\
\hline 25 & $\begin{array}{l}\text { Saat siswa terlihat kebingungan dalam melakukan } \\
\text { praktikum, sebaiknya guru menuntun siswa kembali } \\
\text { melihat cara kerja praktikum yang terdapat pada LKS }\end{array}$ & 34,6 & 61,5 & 3,85 & 0 \\
\hline 26 & $\begin{array}{l}\text { Setelah guru memberikan tugas praktikum di kelas kepada } \\
\text { siswa, guru dapat meninggalkan siswa }\end{array}$ & 53,8 & 34,6 & 7,69 & 3,85 \\
\hline 27 & $\begin{array}{l}\text { Pada saat melakukan praktikum di depan kelas, guru } \\
\text { memberikan kesempatan kepada siswa untuk melakukan } \\
\text { praktikum sendiri }\end{array}$ & 30,8 & 65,4 & 3,85 & 0 \\
\hline 28 & $\begin{array}{l}\text { Setelah praktikum berakhir, guru meminta masing-masing } \\
\text { siswa untuk menarik kesimpulan dari materi yang telah } \\
\text { dipelajari }\end{array}$ & 65,4 & 34,6 & 0 & 0 \\
\hline
\end{tabular}

Hasil penelitian menunjukkan bahwa guru IPA sudah sangat memahami arti pentingnya praktikum dalam pembelajaran IPA. Hal ini dilihat dari jawaban beberapa item pernyataan yang telah diberikan menunjukkan sebagian besar guru IPA menjawab sangat setuju. Misalnya pada pernyataan 
"Guru mengetahui dengan baik pentingnya praktikum dalam pembelajaran IPA", hasil olah data angket menunjukkan 57,7\% responden menjawab Sangat Setuju untuk pernyataan ini, yang artinya guru sangat mengetahui dengan baik pentingnya praktikum dalam pembelajaran IPA. Selanjutnya 38,5 \% responden menjawab Setuju, 3,85 \% reponden menjawab Tidak Setuju dan 0 $\%$ responden menjawab Sangat Tidak setuju. Ini menunjukkan guru di MIN sekabupaten Aceh Jaya telah memahami bahwa metode praktikum harus diterapkan dalam pembelajaran IPA.

Untuk pernyataan "Pembelajaran IPA tidak harus dilakukan dengan metode praktikum", untuk pernyataan tersebut jawaban responden $0 \%$ Sangat Setuju, 61,5\% menjawab Setuju, 30,8\% responden menjawab Tidak setuju, dan 7,69\% responden menjawab Sangat Tidak Setuju. dari jawaban responden tersebut maka dapat diketahui bahwa masih banyak guru yang meyakini metode praktikum tidak penting diterapkan dalam pembelajaran IPA dan dapat diketahui bahwa guru-guru IPA pada MIN di Kabupaten Aceh Jaya masih kurang pemahamannya tentang seberapa besar peran metode praktikum di dalam pembelajaran IPA.

Selanjutnya untuk pernyataan "pembelajaran IPA tidak sekedar melakukan kegiatan praktikum akan tetapi juga mentransfer keterampilan merencanakan penyelidikan ilmiah, merumuskan pertanyaan serta merancang percobaan" Hasil rekapitulasi pada menunjukkan bahwa 42,3\% responden menjawab Sangat Setuju, 53,8\% responden menjawab Setuju, 3,85\% responden menjawab Tidak Setuju dan 0 \% responden menjawab Tidak Setuju. Dapat diketahui bahwa sebagian besar guru IPA MIN di Kabupaten Aceh Jaya telah memahami bahwa praktikum dalam pembelajaran IPA bukan hanya sekedar praktek saja, akan tetapi makna yang sebenarnya adalah melatih keterampilan siswa agar mampu melakukan percobaan sendiri dan merancang percobaan sendiri.

Lebih lanjut hasil olah data tentang persepsi guru IPA MIN dapat dilihat pada Gambar 1 di bawah ini. 


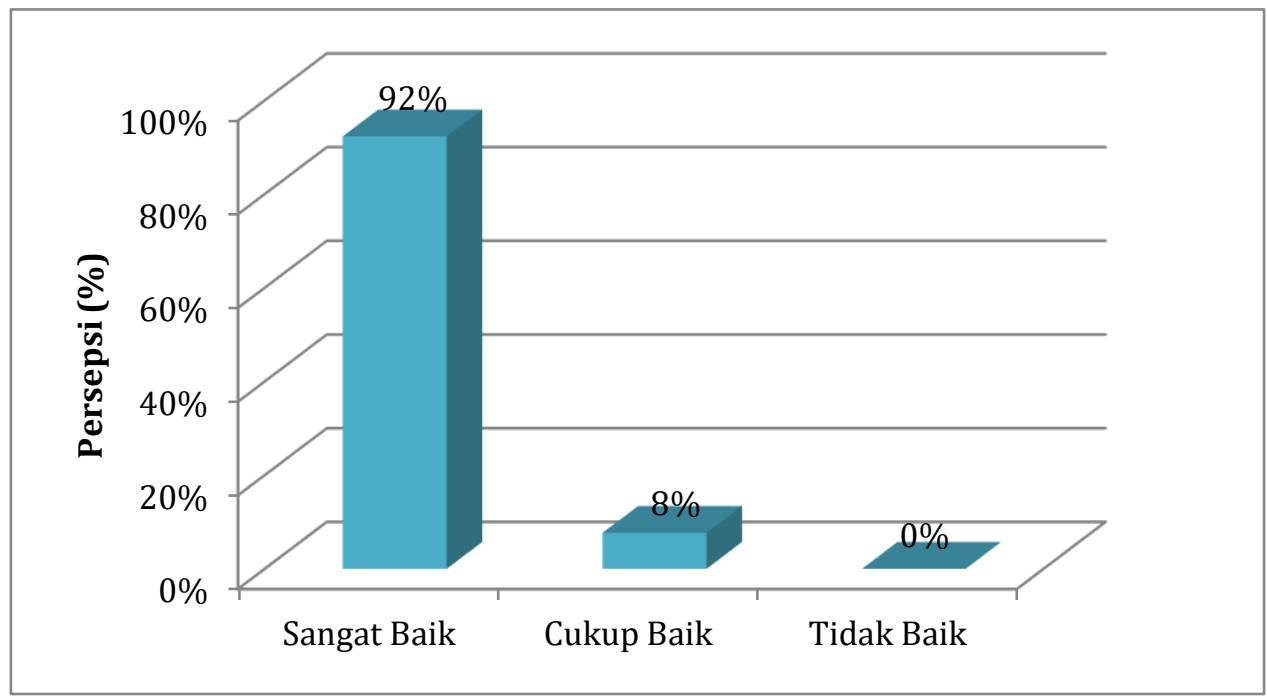

Gambar 1 Diagram Kategori Persepsi Guru IPA

Berdasarkan gambar 1 dapat diketahui bahwa persepsi guru IPA di MIN se-kabupaten Aceh Jaya berada pada kategori "Sangat Baik" yaitu dengan perolehan rata-rata sebesar 92\%. Ini cukup membuktikan bahwa guru IPA di MIN se-kabupaten Aceh Jaya sudah sangat baik pemahamannya dalam melakukan pembelajaran IPA dengan metode praktikum. Meskipun begitu, ternyata masih ada sebagian kecil guru IPA MIN yang masih memiliki persepsi "cukup baik" terhadap pembelajaran IPA dengan metode praktikum. Ini ditunjukkan dari hasil angket sebesar 8\% guru yang berada pada kategori "cukup baik".

\section{Pembahasan}

Sampai saat ini di jenjang sekolah MIN memang belum ada ruang LAB khusus IPA, bahkan di tingkat MTSN pun masih sangat jarang ada sekolah yang memiliki ruang khusus LAB IPA. Sehingga pembelajaran praktikum di tingkat MI hanya dengan menggunakan kotak KIT IPA di kelas belajar, jadi tidak ada ruang khusus pada tingkat sekolah MI yang digunakan sebagai ruang praktikum IPA. Semestinya sekolah pada tingkat MI di haruskan memiliki 
ruang LAB khusus IPA walaupun hanya ruang kelas yang dimanfaatkan sebagai ruang LAB IPA.

Guru harus diharapkan dapat merancang sendiri alat peraga yang akan dipergunakan dalam belajar IPA, untuk pembelajaran IPA yang ada kaitannya dengan lingkungan maka siswa diarahkan untuk belajar di luar kelas. Pemanfaatan lingkungan sekolah dapat dijadikan sebagai acuan untuk memotifasi para pengajar memanfaatkan lingkungan sekolah sebagai sumber belajar untuk membantu meningkatkan hasil belajar siswa (Setiawan \& dkk, 2020; Yanti et al., 2016).

Kurangnya ketersediaan buku paket menjadi suatu kendala terbesar dalam mencerdaskan anak bangsa. Hampir di seluruh sekolah MI Kabupaten Aceh Jaya mengeluhkan ketidaksediaan buku paket K13. Para guru masih memakai buku kurikulum sebelumnya untuk mengambil bahan materi ajar yang akan diajarkan kepada siswa. Meskipun buku teks pelajaran tidak menjadi satu-satunya sumber belajar yang bisa digunakan oleh guru dan siswa, namun adanya buku teks pelajaran yang sesuai dengan kurikulum yang sedang berlaku sangat penting dalam kegiatan belajar mengajar. pemanfaatan sumber belajar di sekolah dasar tidak variatif, sumber belajar yang sangat sering dimanfaatkan pada tingkat sekolah dasar hanya buku teks dan lembar kerja siswa (LKS), sehingga kesediaan sumber belajar seperti buku teks yang baik dan sesuai dengan kurikulum yang sedang berlaku sangat di harapkan oleh para pendidik.

Jadi, ketidaksesuain ini menjadi masalah krusial yang sering terjadi di madrasah, ditambah dengan sertifikasi pendidik bagi guru. Masalah-masalah ini berdampak pada kapasitas guru dalam mengelola proses pembelajaran. Seperti pada sekolah MIN 7, MIN 10, MIN 12 mata pelajaran IPA di ajarkan oleh guru yang berlatar belakang pendidikannya jauh dari ilmu IPA, jika pelajaran IPA diajarkan oleh guru yang bukan berlatar belakang pendidikan IPA, maka guru yang hanya sebatas berpengalaman mengajar IPA akan mengajarkan materi yang tersedia di dalam buku paket saja, dikarenakan keterbatasan 
pemahaman guru tentang pentingnya praktikum dalam pembelajaran IPA dan kurangnya pemahaman guru dalam mengaplikasikan alat-alat yang ada di dalam kotak kit, sehingga kotak kit yang ada di sekolah-sekolah sangat jarang dipergunakan, karna tidak terlalu sering dipergunakan dan tidak tau cara perawatan alat yang baik dan benar sehingga ada sebagian alat yang rusak dengan sendirinya tanpa pernah dipakai.

Walaupun pembelajaran praktikum IPA tidak dengan menggunakan alat-alat yang tersedia di dalam kotak kit dikarenakan keterbatasan pemahaman guru tentang penggunaan alat, namun pembelajaran IPA dengan menggunakan media pembelajaran untuk melakukan praktikum tetap berjalan dengan baik, terkadang dikarenakan terbatasnya pemahaman guru tentang cara pemakaian alat praktikum yang tersedia di dalam kotak kit guru merancang sendiri alat peraga yang akan dipergunakan dalam belajar IPA, untuk pembelajaran IPA yang ada kaitannya dengan lingkungan maka siswa diarahkan untuk belajar di luar kelas. Pemanfaatan lingkungan sekolah dapat dijadikan sebagai acuan untuk memotivasi para pengajar memanfaatkan lingkungan sekolah sebagai sumber belajar untuk membantu meningkatkan hasil belajar siswa.

Oleh karena itu, pelatihan bagi guru-guru yang mengajar IPA sangat dibutuhkan. Agar guru-guru yang ada di kecamatan Lamno sudah lebih profesional dalam mengajar IPA. Ditambah dengan aplikasi strategi yang sama pada guru-guru IPA MIN yang ada di kecamatan Setia Bakti, setidaknya walaupun mata pelajaran IPA tidak diajarkan langsung oleh guru yang berlatar belakang pendidikan IPA, tapi nantinya siswa-siswa di sekolah-sekolah MIN yang ada di kecamatan Setia Bakti diajarkan oleh guru-guru yang terampil dalam menggunakan alat-alat praktikum IPA, maka siswa akan lebih termotivasi dalam belajar sehingga akan menciptakan suasana belajar yang aktif, dan terjalin komunikasi yang baik antara guru dan siswa sehingga dapat meningkatkan motivasi belajar dan hasil belajar siswa. 
Pelatihan bagi guru IPA dalam segi praktikum sangat berdampak positif terhadap guru-guru yang masih sangat kurang pemahamannya terhadap pembelajaran praktikum, sehingga guru masih kurang trampil untuk memanfaatkan alat praktikum. Pembiaran guru dengan kompetensi yang ada atau seadanya dalam mengelola kegiatan pembelajaran adalah sebuah bentuk "penyimpangan akademik". Guru tidak sepantasnya dibiarkan melakukan tindakan auotodidak, melainkan perlu diintervensi sebagai upaya meningkatkan kompetensinya. Untuk itu pelatihan Pembelajaran Aktif, Inovatif, Kreatif, Efektif dan Menyenangkan (PAIKEM) menjadi menu wajib dalam upaya meningkatkan kualitas proses pembelajaran.

Kurangnya ketersediaan buku paket menjadi suatu kendala terbesar dalam mencerdaskan anak bangsa, hampir di seluruh sekolah MIN Kabupaten Aceh Jaya mengeluhkan ketidak sediaan buku paket K13. Para guru masih memakai buku kurikulum KTSP untuk mengambil bahan materi ajar yang akan diajarkan kepada siswa. Meskipun buku teks pelajaran tidak menjadi satu-satunya sumber belajar yang bisa digunakan oleh guru dan siswa, namun adanya buku teks pelajaran yang sesuai dengan kurikulum yang sedang berlaku sangat penting dalam kegiatan belajar mengajar. Pemanfaatan sumber belajar di sekolah dasar tidak variatif, sumber belajar yang sangat sering dimanfaatkan pada tingkat sekolah dasar hanya buku teks dan lembar kerja siswa (LKS), sehingga kesediaan sumber belajar seperti buku teks yang baik dan sesuai dengan kurikulum yang sedang berlaku sangat di harapkan oleh para pendidik.

Menurut informasi juga diketahui bahwa sekolah di bawah naungan kementerian Agama jauh berbeda dengan sekolah di bawah naungan Pemda, jika di bawah naungan pemda walaupun siswanya sedikit, tapi dana operasionalnya tetap diberikan pada batas standar kritria minimum yang sudah ditetapkan oleh kementerian. Sedangkan sekolah-sekolah yang dibawah naungan Kementerian Agama jika memiliki siswa sedikit, maka sedikit pula uang operasional yang diberikan, sehingga uang yang diberikan 
tidak bisa dipakai untuk memesan buku paket dalam jumlah yang banyak, sehingga alternatif yang harus dilakukan adalah memesan buku paket beberapa unit saja selebihnya difotokopi. Barangkali ini terkait dengan pengelolaan dana sekolah yang berpsat di provinsi bukan di daerah.

Media belajar yang baik adalah media belajar yang dapat membangkitkan motivasi siswa untuk belajar, buku paket yang dijadikan salah satu media belajar di sekolah-sekolah dirancang semenarik mungkin dengan paduan gambar serta warna yang bermacam ragam, diharapkan dapat menarik motivasi siswa dalam belajar, tapi jika buku paket yang dibagikan kepada siswa dalam bentu foto kopian, maka buku paket yang telah dirancang semenarik mungkin akan terlihat biasa saja dan cenderung membuat siswa bosan dalam belajar, tapi hanya alternatif itu yang bisa dilakukan oleh pihak sekolah dalam usaha memenuhi kebutuhan buku bagi siswa, karna uang oprasional yang bisa dikeluarkan untuk pembelian buku memang sudah di plotkan jumlahnya dan tidak bisa dipergunakan lebih dari dana yang sudah di tetapkan.

Harapan terbesar guru-guru kelas yang mengajar IPA sekabupaten aceh jaya adanya kepedulian dari pihak pemerintah terutama pihak kementerian agama guna mengadakan pelatihan guru MI terutama dalam memperdalam ilmu pengetahuan IPA dan tata cara penggunaan alat-alat praktikum yang disediakan di dalam kotak KIT. Jika pemahaman guru kurang dalam mengoprasikan alat peraga praktikum, maka akan berdampak pada motivasi belajar siswa, siswa kurang tertarik untuk belajar karena kurangnya media pembelajaran. Adanya perhatian pemerintah terhadap alat praktikum seperti kotak kit yang sudah tidak layak pakai lagi, dan bahkan ada sekolah yang berada di lokasi yang rawan banjir dan sampai sekarang tidak memiliki kotak kit sangat membutuhkan bantuan dari pihak terkait agar pembelajaran IPA dapat berjalan sebagaimana mestinya. 


\section{Kesimpulan}

Berdasarkan penelitian dapat disimpulkan bahwa persepsi guru IPA MIN se-kabupaten Aceh Jaya berada pada kategori "sangat baik" yaitu sebesar 92\% dan sisanya 8\% berada pada kategori "cukup baik". Ini memberikan arti bahwa guru IPA MIN se-kabupaten Aceh Jaya sudah sangat memahami bahwa pembelajaran IPA harus dilakukan dengan metode praktikum, namun karena kurangnya keterampilan guru dalam memanfaatkan bahan yang ada di alam serta sarana dan prasarana yang belum memadai menyebabkan praktikum dalam pembelajaran IPA jarang dilaksanakan.

\section{Daftar Pustaka}

Abdurrozak, R., \& Jayadinata, A. K. (2016). Pengaruh Model Problem Based Learning Terhadap Kemampuan Berpikir Kreatif Siswa. Jurnal Pena Ilmiah, 1(1), 871-880. https://doi.org/10.23819/pi.v1i1.3580

Budiani, S., \& Syamwil, R. (2017). Evaluasi Implementasi Kurikulum 2013 di Sekolah Pelaksana Mandiri. Innovative Journal of Curriculum and Educational Technology, 6(1), 45-57.

Damarwulan, R. A. (2020). Hubungan Pelaksanaan Praktikum dan Keterampilan Generik Sains terhadap Hasil Belajar Peserta Didik. BIOEDUSCIENCE: Jurnal Pendidikan Biologi Dan Sains, 4(1), 56-65. https://doi.org/10.29405/j.bes/4156-653610

Fadilah, I., Sari, R. I., Ramadhani, V., Basuki, F. R., \& Fitaloka, O. (2019). Ethnoscience Study of the Application and Delivery Procession of Adat Melayu Jambi as Science Learning Resources. Scientiae Educatia, 8(2), 141. https://doi.org/10.24235/sc.educatia.v8i2.4428

Fauzan, M., Gani, A., Syukri, M., Aceh, D. B., \& Banda, D. (2017). Penerapan Model Problem Based Learning Pada Pembelajaran Materi Sistem Tata Surya Untuk Meningkatkan Hasil Belajar Siswa. Jurnal Pendidikan Sains Indonesia (Indonesian Journal of Science Education), 5(1), 27-35.

Forefry, N. (2017). Strategi Pemberdayaan Guru oleh Sekolah ( Studi Kasus di SMAN 5 dan SMADarul Hikam Kota Bandung ). Jurnal Administrasi Pendidikan, XXIV(1), 47-59.

HUSNA, H. (2011). Pengaruh Penerapan Model Pembelajaran Arias Disertai Tugas Awal Terhadap Hasil Belajar Fisika Siswa Kelas XI IPA SMAN 8 Padang. Jurnal Pelangi, 3(2). https://doi.org/10.22202/jp.2011.v3i2.30

Jalil, M. (2019). The Effectiveness of Simulation Methods on Prospective Teachers' Professionalism in Science Learning. Scientiae Educatia, 7(2), 129. https://doi.org/10.24235/sc.educatia.v7i2.2482

Kastina, Z. V. K., \& Sujianto, S. (2017). Implementasi Sistem Penilaian dalam 
Kurikulum 2013 di SMA Negeri 2 Pekanbaru. Jom Fisip, 4(1), 1-15.

Kumalasari, M. (2019). Analisis Respon Guru Dan Peserta Didik Terhadap Lkpd Ipa Berbasis Inkuiri Terbimbing Yang Terintegrasi Ayat Al-Quran Dan Hadist Di Smp Askhabul Kahfi. Edu Sains Jurnal Pendidikan Sains \& Matematika, 7(1), 41-48. https://doi.org/10.23971/eds.v7i1.1034

Nafiah, Y. N., \& Suyanto, W. (2014). Penerapan model problem-based learning untuk meningkatkan keterampilan berpikir kritis dan hasil belajar siswa. Jurnal Pendidikan Vokasi, 4(1), 125-143. https://doi.org/10.21831/jpv.v4i1.2540

Nur, F. M. (2012). Pemanfaatan Sumber Belajar dalam Pembelajaran Sains Kelas V SD Pada Pokok Bahasan Makhluk Hidup dan Proses Kehidupan Oleh: Faizah M. Nur. Jurnal Penelitian Pendidikan, 13(1), 67-78.

Pantiwati, Y. (2015). Pemanfaatan Lingkungan Sekolah sebagai Sumber Belajar dalam Lesson Study untuk Meningkatkan Metakognitif. Jurnal Bioedukatika, $3(1)$,

27. https://doi.org/10.26555/bioedukatika.v3i1.4144

Setiawan, A., \& dkk. (2020). The Effect of Curriculum 2013 on Economics Learning Achievement: Motivation As Mediating Variable Ananda. Cakrawala Pendidikan, 39(2), 444-459. https://doi.org/10.21831/cp.v39i2.30279

Yanti, D. E. B., Subiki, \& Yushardi. (2016). Analisis Sarana Prasarana Laboratorium Fisika Dan Intensitas Kegiatan Praktikum Fisika Dalam Mendukung Pelaksanaan Pembelajaran Fisika Sma Negeri Di Kabupaten Jember. Jurnal Pembelajaran Fisika, 5(1), 41-46. 